Environment Protection Engineering

Vol. 11

1985

No. 1

BRIAN BOLTO *, LUCJAN PAWŁOWSKI**

\title{
ION EXCHANGE FOR THE RECYCLING OF WASTEWATER CONSTITUENTS
}

\begin{abstract}
Recycling of the constituents of wastewater requires efficient and cheap separation methods. Pollutants must be removed in a concentrated form to facilitate their recycling. Similarly, the raw water must be purified to a level necessary for water reuse. One very efficient method for the separation of ions from liquids is ion exchange, which has greater than eurrently realised utility for the treatment of wastewater.

The application of ion exchange to the recovery of metals, nutrients and rare chemicals as well as water from industrial effluents and sewage is summarized. Attention is given to the ways of improving the economics of recovery. One method of making the recovery processes simpler and less costly is to employ magnetic resins. Because of their excellent kinetic properties the size of the equipment needed is minimized. The present and future possible applications of magnetic resins are reviewed.
\end{abstract}

\section{INTRODUCTION}

The American philosopher, B. FULLER, remarked that a pollutant is a seawater resource. Looking through Man's industrial activities, one finds many examples that confirm Fuller's opinion. Water is possibly the most important substance in Nature, and its value as a resource diminishes with pollution.

Generally, the direct consumption of water in industrial processes is rather low. Water is mainly used as a reaction medium, for washing purposes and for the transportation of materials and energy. During its use water becomes a medium for some chemicals which are often toxic to the environment.

* CSIRO Division of Chemical and Wood Technology, Private Bag 10, Clayton 3168, Australia.

** Visiting scientist at CSIRO, from Technical University of Lublin, 20-618 Lublin, Poland. 
In recent years, more and more attention has been paid to multiple reuse of water because of shrinking of the world's fresh water resources. There has been increasing development of technologies which allow the purification of wastewater to the extent that the recovered water can be recycled to production.

However, less attention has been paid to recycling the chemicals contained in wastewater, partly because their value in such a dilute state is usually lower than that of water, and therefore the economic motives for their separation are not strong enough. Nevertheless, there are circumstances in which it may be economical to recover certain components from wastewater, particularly when the component occurs in large quantities. As nonrenewable resources become exhausted, their market price increases to the point where their recovery becomes an economic proposition. Alternatively, punitive social costs are imposed on the polluter who passes them onto the consumer.

An example is the processing of nitrogen compounds. About $0.3 \%$ of ammonia produced is discharged to the environment as a pollutant, and losses of nitric acid are even higher, reaching $1.3 \%$. Obviously, the recovery of such amounts of nitrogen compounds should not be neglected. The losses of heavy metals in metal finishing operations are even higher.

By implementing recycling one may paraphrase Fuller's statement and say that a pollutant is a recoverable resource. However, to develop this type of approach for the pollutants in wastewater one has to have suitable separat ion and concentration techniques. One of the most promising methods is ion exchange. The objective of this paper is to present ion exchange as a useful technique solving some of today's environmental and resource problems.

\section{GENERAL DESCRIPTION OF ION EXCHANGE PROCESSES}

Ion exchange allows the separation of ionic solutes from liquids, and of one solute from another. The selection of the method of separation depends above all on the composition of the solution to be treated and on the removal efficiency. Two kinds of operation may be distinguished: selective removal of ionic impurities and full deionization. There are some types of highly concentrated ionic wastes consisting of exhausted processing solutions, e.g. spent plating baths. During processing impurities remain in the bath and the bath liquor deteriorates. These wastes are a serious hazard to the environment as they contain high concentration of pollutants. Ion exchange provides solution to this type of waste problem since making possible the removal of the contaminating ions renders the spent bath useful again. The conditioning of the spent solutions may be done by selective removal of undesirable ions and by separation of acid from salt, using the method of acid retardation [27]. 
In many cases industrial wastewaters such as rinse waters and condensates contain only undesirable ions and then a full deionization is required. In other cases deionization is necessary to implement a closed-loop system in plating operations; in such cases both chemicals and water are recycled.

Examples of both selective removal and full deionization are mentioned below. A comprehensive review of these problems has been prepared for publication elsewhere [12].

\subsection{SELECTIVE REMOVAL OF IONIC IMPURITIES}

It is often necessary to remove one kind of ionic impurity from a mixture of impurities contained in a wastewater. Generally, by application of ion exchange undesirable ions are replaced by the others which are not harmful to the environment. A typical example of this concept is given by the recovery of precious metals, where the treatment process aims at a complete retention. In this case water reuse is of far less economic importance and often the volume of effluent is relatively small. Some plating effluents contain gold in the form of an anionic complex $\left[\mathrm{Au}(\mathrm{CN})_{2}\right]$ from which this anion can be removed by using a standard, strongly basic or a quaternized polyvinylpyridine anion exchanger.

In one application, where the plating rinse water contained $4-5 \mathrm{mg} \mathrm{Au} / \mathrm{dm}^{3}$, a two-column system was used for its adsorption [42]. A weakly acidic cation exchanger in the H-form (Diaion WK20) was used, presumably to remove other heavy metal cations and to lower the $\mathrm{pH}$, followed by a weakly basic anion exchanger (Lewatit MP62). The anionic gold was adsorbed on the anion exchanger.

Another plating effluent, containing anionic gold together wirh organic acids and their salts, was treated with a weakly basic anion exchanger at $\mathrm{pH} \sim 3$, on a three-column system arranged in series [29]. The gold was retained in the first bed and the other solutes on the second and third beds. For the removal of anionic gold from highly acidic solutions, a polyisothiouronium resin (Srafion NMRR) can be used. For various precious metals total capacities of $80 \mathrm{~g}$ of metal $/ \mathrm{dm}^{3}$ of resin [13b] are as follows: $\mathrm{Rh}-80, \mathrm{Au}-340, \mathrm{Pt}-200, \mathrm{Pd}-$ 120. Nevertheless, for gold the operating capacity of this resin is low $(55-110 \mathrm{~g}$ $\mathrm{Au} / \mathrm{dm}^{3}$ resin) [13b]. Because the value of the gold retained in the resin greatly exceeds that of the spent resin, in a common practice the metal is recovered by incinerating the resin at $1000^{\circ} \mathrm{C}$. However, a solution of $5 \% \mathrm{NaOH}+5 \%$ $\mathrm{NaCH}$ is also used for regeneration of the resin.

Another precious metal widely used in plating and photographic industry is silver. In plating, silver is used as a cyanide complex with various additives, and the resultant effluents can contain $\left[\mathrm{Ag}(\mathrm{CN})_{2}\right]^{-}, \mathrm{KCN}$ and $\mathrm{K}_{2} \mathrm{CO}_{3}$. For 
the adsorption of the silver complex, a strongly basic anion exchanger is employed, such as Amberlite IRA-400 [43]. In another application two ion-exchange columns in series were used; one containing a weakly acidic cation exchanger and the other a weakly basie anion exchanger [44].

In a further example, a plating effluent containing $\mathrm{Ag}: 14.2, \mathrm{Cu}: 3.8, \mathrm{CN}$ : 17 and COD : $5.4 \mathrm{mg} / \mathrm{dm}^{3}$ was passed through a series of beds: the first - a weakly basic resin, the second - a resin of medium basicity and the third a strongly basic anion exchanger (the last one to prevent leakage of $\mathrm{CN}^{-}$). Demineralized water (containing very small amounts of $\mathrm{Ag}^{+}, \mathrm{Cu}^{+2}$ and $\mathrm{CN}^{-}$, each $<0.1 \mathrm{mg} / \mathrm{dm}^{3}$ ) was obtained. Silver was recovered from the first bed [58].

The recovery of silver is very important in the photographic industry, the effluents from which contain the metal in an anionic form, $\left[\mathrm{Ag}\left(\mathrm{S}_{2} \mathrm{O}_{3}\right)_{2}\right]^{-3}$. A strongly basic anion exchanger is usually used for its recovery [20]. For example, with Duolite AlOLD, a decrease in the silver content from 7 to $0.05 \mathrm{mg} / \mathrm{dm}^{3}$ is obtained. The weakly basic resin Amberlite IRA 68 has also been used for the recovery of silver from photographic effluents. The weakly basic resin has a lower capacity, but it is easily regenerated with an alkaline solution which also allows a higher concentration of silver to be obtained in the regeneration effluent. Electrolysis is used for the final recovery of silver [16], [41]. Because of the lower value of silver, incineration of the exhausted resin is not practised and regeneration is achieved with $5 \% \mathrm{NaOH}$ and $5 \% \mathrm{KCN}$ [44] or solutions of $\mathrm{NH}_{4} \mathrm{Cl}[20]$.

The recovery of selenium, the salts of which are used in the electrolytic colouring of metals, is also practised by ion exchange. The rinse water as well as the exhausted bath liquor contains selenium oxy-acids. A two-column system is used to recover selenium: the first column, containing a chelate resin, removes heavy metal ions while the second, containing an anion exchanger, removes the selenium oxy-acids. The anion exchanger is regenerated with $0.5 \mathrm{~N} \mathrm{NaOH}$ and the regeneration effluent contains $5.5 \mathrm{~g} \mathrm{Se} / \mathrm{dm}^{3}$ [35], [52], [54].

Tin is also used in electrolytic coating operations. The rinse water can be treated with a two-column system: the first containing a strongly acidic cation exchanger and the second a weakly basic resin. Tin is recovered from the latter by elution with caustic soda [28].

A strongly basic anion exchanger is used for the recovery of molybdenum [53] and arsenic ions [56]. An ion-exchange method is also used for the recovery of lithium [23]. An interesting method was developed for recovery of boric acid from radioactive wastewater. The effluent is cooled to $4-10^{\circ} \mathrm{C}$, then passed through an anion exchanger bed which retains the boric acid. The resin is regenerated with warm $\left(60-70^{\circ} \mathrm{C}\right)$ water [32]. An ion-exchange method has been used for the recovery of vanadium from the effluent of zirconium vanadium pigment manufacture [60]. 
Mercury is one the worst pollutants, having caused serious disasters in Japan and Iran. Most mercury arises from chlorine and caustic manufacturing plants. Reuse of mercury from wastewater treatment reduces the cost of wastewater treatment by about $25 \%$ [13a]. The Imac TMR resin is a polymeric mercaptan in which the thio (-SH) groups have a high affinity for mercury [18], [55]. The operational ion-exchange capacity depends on the mercury concentration in the effluent and ranges from $48 \mathrm{~g} \mathrm{Hg} / \mathrm{dm}^{3}$ to $100 \mathrm{~g} \mathrm{Hg} / \mathrm{dm}^{3}$. for mercury concentration of $0.6 \mathrm{mg} \mathrm{Hg} / \mathrm{dm}^{3}$ and $10 \mathrm{mg} \mathrm{Hg} / \mathrm{dm}^{3}$, respectively. Concentrated $(35 \%) \mathrm{HCl}$ was used to regenerate the exhausted resin [23].

A resin known as Srafion NMRR, which contains isothiouronium groups, is also used for mercury removal. Its capacity for chloride ions is $3.1 \mathrm{meq} / \mathrm{g}$ resin and for mercury $0.545 \mathrm{~g} \mathrm{Hg} / \mathrm{g}$ of resin. The resin can be regenerated with a $5 \%$ solution of thiourea containing $2.2 \mathrm{~g} \mathrm{HCl} / \mathrm{dm}^{3}$. Other mercury selective: anion exchangers are known.

It is also possible to use conventional resins for the removal of mercury

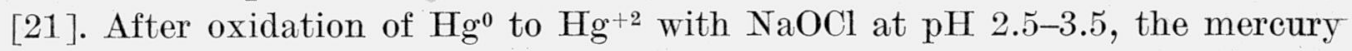
can be adsorbed as the complex $\left(\mathrm{Hg} \mathrm{Cl}_{4}\right)^{-2}$ onto an ion exchanger such as Wofatit SBW or Varion AD. When $12 \mathrm{~N} \mathrm{HCl}$ is employed for regeneration, $85 \%$ of the mercury can be eluted from the ion-exchange bed.

A very important application of ion exchange is found in the recovery of copper from leaching operations in copper production. Because of the low $\mathrm{pH}(<2)$ normal chelate resins do not adsorb the copper ions. Two specific resins have been developed, which have a high affinity for copper over other metal ions [25], [26], [34], [59]. They are based on $\mathrm{N}$ (hydroxyalkyl)picolylamines. One of the resins (Dowex XFS-4195) can even take up copper ions from $3 \mathrm{~N} \mathrm{H}_{2} \mathrm{SO}_{4}$, but a more concentrated acid $(1 \mathrm{ON})$ is required for regeneration. The other resin (Dowex XFS-4196) can take up copper ions from less: acidic solutions having $\mathrm{pH}>1.5$, and can be regenerated adequately with sulfuric acid of concentration $100 \mathrm{~g} \mathrm{H}_{2} \mathrm{SO}_{4} / \mathrm{dm}^{3}$. The regeneration effluent contains $33 \mathrm{~g} \mathrm{Cu}^{+2} / \mathrm{dm}^{3}$ and $40 \mathrm{~g} \mathrm{H}_{2} \mathrm{SO}_{4} / \mathrm{dm}^{3}$. It can be used for production of copper in the electro-winning process. The consumption of $\mathrm{H}_{2} \mathrm{SO}_{4}$ amounts to about $1.7 \mathrm{~g} / \mathrm{g}$ of $\mathrm{Cu}$, i.e. only $10 \%$ greater than the stoichiometric requirement $\left(1.54 \mathrm{~g} / \mathrm{dm}^{3}\right)$ [26]. Recently a new resin (Dowex XFS-43084) has been developed which is similar to Dowex XFS-4196, but has a higher preference for copper over iron ions [26].

There are some wastewaters which contain up to several grams per litre of ammonium sulfate and low concentrations of copper ions. It is possible to use such effluents for irrigation, but the copper ions have to be removed. An ionexchange method has been used for this purpose to produce concentrated copper sulfate, which may be recycled [33].

Another interesting application of ion exchange is its participation in the treatment of wastewater from gas desulfurization. The effluent contains, 
among others, nickel and vanadium, which can be recovered. The effluent is oxidized and its $\mathrm{pH}$ is adjusted to $5-10$ before it is passed through a chelate resin bed where nickel ions are adsorbed. The $\mathrm{pH}$ of the effluent from this operation falls below 5. The solution is then passed through the next chelate resin bed where vanadium ions are adsorbed [31]. At regeneration, the concentrated solutions obtained yield useful by-products.

Zinc may be removed from wastewaters as the cation, however, its removal as the anion $\left(\mathrm{ZnCl}_{4}\right)^{-2}$ is also possible. In the presence of $\mathrm{HCl}$ zinc forms the anionic complex which can be easily retained on the anion exchange bed. By washing the exhausted anion exchanger with water pure $\mathrm{ZnCl}_{2}$ [40] may be obtained. This concept allows separation of zine ions from a regeneration effluent containing a mixture of metals. For example, a strongly acidic cation exchanger is used for the removal of metals from mixed plating effluents. $\mathrm{By}$ using an excess of $\mathrm{HCl}$ for the regeneration of the exhausted eation exchanger one obtains a mixture of the chlorides. Further treatment of this regeneration effluent with an anion exchange resin results in the selective adsorption of $\left(\mathrm{ZnCl}_{4}\right)^{-2}$.

Zine is used in the koalin industry. A strongly acid cation exchanger in the $\mathrm{Na}^{+}$form can be used to remove zine ions from effluents. With the use of $300 \mathrm{~g} \mathrm{NaCl} / \mathrm{dm}^{3}$ resin for regeneration it is possible to obtain a capacity of 32-40 $\mathrm{g} \mathrm{Zn}^{+2} / \mathrm{dm}^{3}$ resin and a zinc leakage below $0.4 \mathrm{mg} \mathrm{Zn}^{+2} / \mathrm{dm}^{3}$ [1]. The removal of zine from the blow-down of water from cooling towers is also a problem which may be successfully solved by ion exchange [15].

Let us now summarize some of the methods for the selective removal of heavy metals. Fortunately, the selectivity of even strongly acidic cation exchangers favours the uptake of polyvalent cations from dilute solutions. Weakly acidic resins (carboxylic acid type) also have a high affinity for heavy metals. Thus, even with the use of conventional resins, it is possible to obtain selective removal of heavy metals from effluents. In the case of the weakly acidic resins, regeneration is very easily accomplished with acidic solutions, as these resins have a high affinity for hydrogen ions. Since, however, they are sensitive to the $\mathrm{pH}$ of the solution to be treated, they are not able to take up metal ions in an acidic environment.

Specific resins for the selective removal of ions are also known. They are documented in the literature [13c], [14]; some commercially available types are listed in tab. 1. Often, other ions are also taken up by the ion exchange resin. Direct elution will lead to a regeneration effluent which contains high levels of undesirable ions. In these eases, pretreatment of the exhausted resin with some of the desirable ions is recommended. These ions will replace the undesirable ions in the ion exchange bed, so that the final regeneration effluent will contain mainly the desirable ions.

The choice of a chelate or a carboxylic resin depends on the particular 
Commercially available chelate resins [14]

Dostępne w handlu wymieniacze jonowe [14]

\begin{tabular}{lll}
\hline \multicolumn{1}{c}{ Manufacturer } & \multicolumn{1}{c}{ Resin } & \multicolumn{1}{c}{ Chelate group } \\
\hline Akzo Chemie & IMAC GT-73 & weakly acidic \\
Diamond Shamrock & Duolite ES-346 & amidoxime \\
& Duolite ES-466 & iminodiacetic acid \\
& Duolite ES-467 & amino-phosphonic \\
Dow & Dowex A-1 & iminodiacetic acid \\
& Dowex XF-4195 & weakly basic \\
Nippon Soda & Dowex XF-4196 & weakly basic \\
Mitsubishi & Nisson ALM-525 & carbamate \\
& Diaion CF-10 & iminodiacetic acid \\
& Diaion CR-20 & polyamine \\
etheleneimine
\end{tabular}

case. For example, the effectiveness of the weakly acidic resin Amberlite DP-1 is equivalent to that of the ehelate resin Amberlite IRC-718 for the removal of zine ions. However, when a $10 \% \mathrm{HCl}$ regenerant is used at a flow rate of $8 \mathrm{BV} / \mathrm{h}$, the concentration of recovered zinc ions is higher for the carboxylic acid resin. Similar results were obtained for effluents containing $\mathrm{Pb}^{+2}$ or $\mathrm{Cd}^{+2}$ ions. However, for an effluent containing copper ions together with ammonium sulfate, the chelate resin is superior. Both the resins are sensitive to flow rate, the carboxylic acid resin being, however, more affected within capacity decreasing as the flow rate increases [57].

If a strongly acidic cation exchanger is applied to the recovery of metal ions from solutions containing a high level of alkali metal ions, the ratio of ions taken up by the cation exchanger makes it impossible to recycle the regeneration effluents. This occurs, for example, in the recovery of zinc from the effluents of synthetic fibre plants (where the concentrations are $\sim 540 \mathrm{mg}$ $\mathrm{Zn}^{+2} / \mathrm{dm}^{3}$ and $\left.10300 \mathrm{mg} \mathrm{Na} / \mathrm{dm}^{3}\right)$. For recycling to be practical, the high content of $\mathrm{Na}_{2} \mathrm{SO}_{4}$ should be lowered to less than $20 \%$. This can be done by 
a two-step regeneration process: elution with $1 \% \mathrm{H}_{2} \mathrm{SO}_{4}$ for partial removal of $\mathrm{Na}^{+}$, followed by regeneration with $10 \% \mathrm{H}_{2} \mathrm{SO}_{4}$ for elution of $\mathrm{Zn}^{+2}$ from the bed [45]. A similar effect can be obtained by pretreatment of the ion exchange bed with a solution containing $\mathrm{Zn}^{+2}$, which displaces $\mathrm{Na}^{+}$ions from the cation exchanger and thus, improves the $\mathrm{Zn}^{+2} / \mathrm{Na}^{+}$ratio in the bed.

The removal of microbial and plant nutrients from wastewater is one of factors preventing eutrophication of receiving waters. The largest amounts of nutrients are contained in agricultural run-off and their substantial amounts being also due to fertilizer industry. In order to remove nutrients from various wastewaters, ion exchange methods can be applied.

An interesting attempt to use ion exchange for the recovery of ammonium and phosphate ions has been made by LIBERTI [37]-[39]. The method is based on the selective adsorption of ammonium ions (on clinoptilolite) and phosphate (on an anion exchanger), and on the $\mathrm{MgNH}_{4} \mathrm{PO}_{4}$ precipitation from the regeneration effluents.

\subsection{FULL DEIONIZATION}

In many industrial plants, various components may be separated from wastewaters (chiefly various rinse waters and condensates). Undesirable toxic ions which may be valuable as reclaimed chemicals must be removed. For such wastewaters a full deionization is the best purification procedure as it produces demineralized water which simplifies recycling. The general flowsheet of such a process is shown in fig. 1 .

One of the important applications of this approach is the closed-loop systems of plating operations, in which both reclaimed chemicals and water are returned to production. In once-through rinsing operations tap water is used. Then, however, the reclamation of chemicals is complicated because the water contains ions contaminating the recovered solutions. Therefore, only demineralized water should be used for rinsing.

The whole treatment consists of the following processes:

separation of suspended matter,

removal of organic matter,

decationization of rinse water,

deanionization of rinse water.

For the separation of suspended solids and organic matter, one of the established conventional methods can be used.

The decationization is similar to that of boiler feed water. Because of the low $\mathrm{pH}(<2)$ of the rinse water a strongly acidic cation exchanger must be used. Some attention must also be given to the oxidizing properties of the rinse water. The regeneration of the exhausted cation exchange bed is performed in a conventional way, preferably with the cheaper sulfuric acid but 
hydrochloric acid is also recommended [22], [50]. Regeneration with $\mathrm{HCl}$ eliminates the difficulty in formation of $\mathrm{CaSO}_{4}$ precipitates when the water balance is maintained by topping up the system with fresh but hard water [50]. Because of the strong bonding of polyvalent heavy metal cations with resin, a high dose of acid is required for regeneration. The recommended amounts

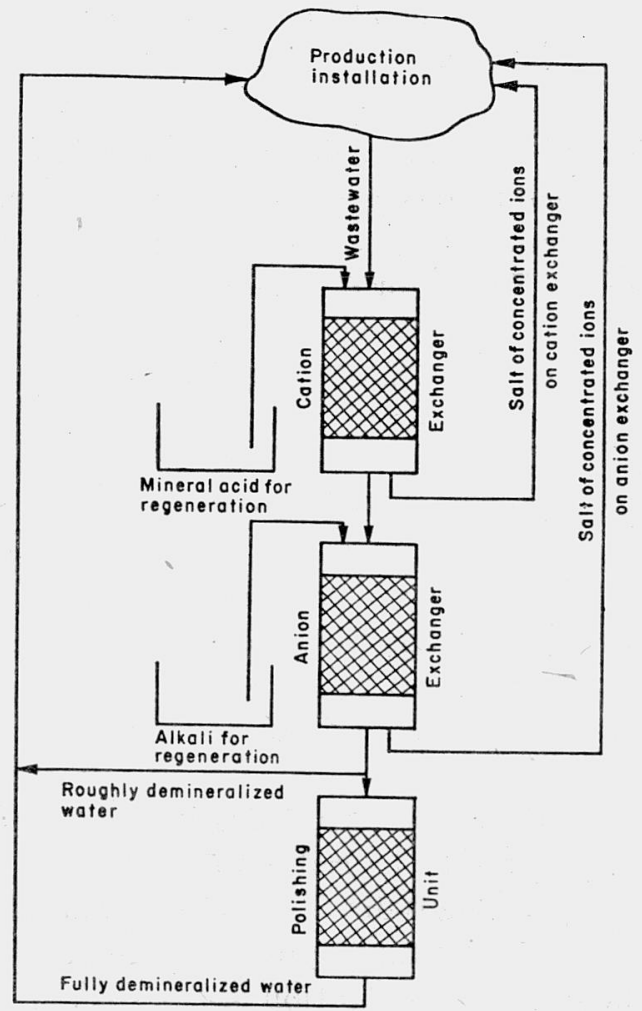

Fig. 1. Flow-sheet for the recycling of all wastewater constituents by ion exchange Rys. 1. Schemat technologiczny zwracania do obiegu wszystkich składników ścieku poprzez wymiane jonową

range from $32 \mathrm{~g} \mathrm{H}_{2} \mathrm{SO}_{4} / \mathrm{dm}^{3}$ of resin at $10 \%$ concentration [52] to $490 \mathrm{~g}$ at $7 \%$ concentration [17]. The consumption of acid can be reduced to a level below $200 \mathrm{~g} / \mathrm{dm}^{3}$ of resin if the heavy metals are precipitated prior to decationization. The regeneration effluent (which contains a mixture of $\mathrm{Fe}_{2}\left(\mathrm{SO}_{4}\right)_{3}$, $\mathrm{Cr}_{2}\left(\mathrm{SO}_{4}\right)_{3}, \mathrm{Na}_{2} \mathrm{SO}_{4}$ and $\mathrm{H}_{2} \mathrm{SO}_{4}$, or the corresponding chlorides and hydrochloric acid) does not have any value and is therefore discharged after neutralization with lime, followed by clarification. The amount of generated wastewater does not exceed $2-5 \%$ of the total volume of rinse water.

The anion exchanger unit is most important for the recovery of chemicals. Deanionization can be performed with or without recovery of chromic acid. 
When the amounts of rinse water are small, then the chromic acid may be recycled; in this ease regeneration of the anion exchanger is performed with a $4 \%$ solution of $\mathrm{NaOH}$. Chromates present in the regeneration effluent are reduced to trivalent chromic ions, and, after neutralization with lime, the clarified wastewater is discharged to the sewer. For the conversion of chromates to chromic acid, the regeneration effluent from the anion exchange (a mixture of $\mathrm{Na}_{2} \mathrm{CrO}_{4}$ and $\mathrm{NaOH}$ ) has to be decationized with a strongly acidic eation exchanger.

For the adsorption of chromic acid onto an anion exchange bed, either strongly basic [22] or weakly basic anion exchange resins [46] may be used. Strongly basic resins permit low leakage of chromate $\left(<1 \mathrm{mg} / \mathrm{dm}^{3}\right)$, but they require greater amounts of $\mathrm{NaOH}$ for regeneration because of its lower efficiency; a weakly basic resin has a higher level of leakage but it consumes less $\mathrm{NaOH}$. The use of a weakly basic resin has some advantages over a strongly basic one, because the closed-loop system does not require a very low content of $\mathrm{Cr}(\mathrm{VI})$ in contrast to the stringent limits imposed for environmental reasons when discharging the wastewater. In rinse tank systems, parts of the metals are immersed in the rinse water, where the concentration of $\operatorname{Cr}(\mathrm{VI})$ is kept at a level of $50-200 \mathrm{mg} / \mathrm{dm}^{3}$ by the continuously flowing water which carries out some of the $\mathrm{Cr}$ (VI) (equivalent to the 'drag out' from plating baths). When make up water containing some $\mathrm{Cr}(\mathrm{VI})$ is used and its concentration is lower than in the rinse tank, then its increase in the rinse-tank is prevented, provided that rinse flow rates are higher.

Obviously, the level of leakage of $\mathrm{Cr}(\mathrm{VI})$ is not the most important factor in a closed-loop rinsing system. The critical factor is the decrease in the $\mathrm{NaOH}$ consumption which very strongly influences the economics of rinse wate $c$ pretreatment. Another extremely important parameter is the concentration of the regeneration effluent. For regeneration of the strongly basic anion exchanger in the conventional manner, a dose of $80-140 \mathrm{~g} \mathrm{NaOH} / \mathrm{dm}^{3}$ of resin at $4 \%$ concentration is recommended [36]. However, as was shown by the use of weakly basic resins regenerated with highly concentrated caustic soda [46], it is possible to get regeneration effluents containing up to $160 \mathrm{~g} \mathrm{Na}_{2} \mathrm{CrO}_{4} / \mathrm{dm}^{3}$. In cases where a hot plating bath is used, the regeneration effluent can be recycled without its concentration by evaporation. The recovery of nickel in metal finishing plants is possible only when the nickel-bearing effluent is separated from the other process streams. Nickel is usually used in form of sulfate, thus its recovery in this form requires the usage of sulfuric acid. Nickel is taken-up on a strongly acidic cation exchanger in the decationizing unit, of the ion exchange plant. Since the regeneration effluent contains too much sulfuric acid, a two-step procedure is recommended. Firstly, the part of the regeneration effluent rich in nickel sulfate is neutralized with $\mathrm{NiCO}_{3}$ and reused to reconstitute the solutions in the bath. The remainder is then collected and used for the first part of regeneration. The decationized effluent is deanionized 
on an anion exchange unit, and the demineralized water is recycled. The regeneration effluent from the anion exchange unit is discharged as waste. About 96-160 $\mathrm{g} \mathrm{H}_{2} \mathrm{SO}_{4} / \mathrm{dm}^{3}$ of resin is required for regeneration of the cation exchanger, the capacity of the resin being $19-29 \mathrm{Ni}^{+2} / \mathrm{dm}^{3}$ [22]. Other metal-bearing rinse waters, including copper, zinc, cadmium and cobalt ones, can be similarly recycled.

Another area where full deionization can be used is the purification of condensates. Evaporation of solutions gives the condensates which may contain several to a few thousand milligrams of solutes per litre. One of the best known examples is recycling of condensate constituents (water, ammonia and nitrates) from the fertilizer industry. Full demineralization of the condensates by ion exchange results in the production of water and concentrated ammonium salts. The water is used as boiler feed water. Decationized condensate obtained from ammonium nitrate processing can be used instead of demineralized water for absorption of nitrogen oxides in nitric acid processing.

The ion exchange processes used for recycling the condensate constituents of the nitrogen industry can be conveniently and arbitrarily divided into two parts: the recovery unit and the water polishing unit. Such a division facilitates the arrangement of the published data.

The main aim of the recovery unit is the rough separation of water and solutes and to increase the concentration of the latter to the highest possible level, i.e. to divide the condensate into roughly demineralized water and concentrated salts. For some purposes such a roughly demineralized water can be used withouth further treatment, for many others, however, (e.g. as boiler feed water) it is too dirty, thus a polishing unit is often required. A mixed bed can be used to polish the roughly demineralized condensate from the processing of ammonium nitrate or sulfate. However, polishing of the analogical roughly demineralized condensate (from ammonia processing) depends on its chemical composition which varies from plant to plant. In some cases the condensate contains only ammonium carbonate, but often significant amounts of chloride and sulfate are also present. Efficient polishing methods are based on the demineralization processes of low salinity waters. In many cases, by placing a weakly basic anion exchanger bed before the mixed bed, savings in caustic soda are obtained and working cycles of the mixed bed are prolonged. The regeneration of the polishing units should be carried out in the same manner as in conventional ion exchange demineralization plants. Roughly demineralized water can be moreover mixed with raw water in a conventional ion exchange unit; all nitrogen plants are equipped with such units for boiler feed water processing as well as for some process requirements.

The use of conventional ion exchange equipment simplifies the technology used for recycling of the condensate constituents. The most important factor affecting the economics of the ion exchange method is concentration of the regeneration effluent. To this end special continuous counter-current columns 
are used. There are several systems specially designed for treatment of nitrogen fertilizer effluents. The Chem-Seps system is based on the Higgins contractor. The regenerants for the cation exchanger and for the weakly basic anion exchanger are a $22 \%$ nitric acid solution and a $7 \%$ ammonia solution, respectively. The content of ammonium nitrate in the regeneration effluent varies from $16-24 \%$ [30], [49], and normally over $97 \%$ nitrogen removal is expected. Another continuous counter-current system has been developed by ARION [4], [48].

It is based on a specially designed column in which the resin is dewatered at the end of each cycle. The cation exchanger is regenerated with $45-60 \%$ nitric solution at $20^{\circ} \mathrm{C}$ and the weakly basic ion exchanger with $20-25 \%$ ammonia solution. The regeneration effluents are recycled for production of ammonium nitrate.

The use of concentrated $(30-60 \%)$ nitric acid solutions for the regeneration of fixed beds has been also investigated. The main problem is to ensure uniform flow of the regeneration effluent through the ion exchange bed. Since the regenerant occupies only a small part of the bed, it flows through the bed as a chromatographic band. The method permits the production of regeneration effluents up to $26 \%$ ammonium nitrate.

Introduction of regeneration effluents containing ammonium sulfate to ammonium nitrate processing increases the physical durability of the ammonium nitrate granules which improves their quality as a fertilizer. Attention has therefore been paid to the use of sulfuric acid for regeneration of the cation exchanger. An additional advantage of this approach is that sulfuric acid is a much weaker oxidation agent than nitric acid. When concentrated sulfuric acid is used, the concentration of $\left(\mathrm{NH}_{4}\right)_{2} \mathrm{SO}_{4}$ in regeneration effluent may reach $24 \%$ [47]. Hence, sulfuric acid can also be used when the cation exchanger for recycling the regeneration effluent is to be regenerated.

In all the cases the chemicals (nitric acid, sulfuric acid and ammonia) are returned to the manufacturing system. On their way through the ion exchange unit they take up some water. As for evaporation of the unwanted (excess) water additional energy must be expected, the efficiency of regeneration should be expressed by the ratio of unwanted "dilution water" recycled by the regenerating dgents (nitric acid, sulfuric acid, ammonia) to the recovered chemicals or to the treated effluent [47].

\section{NEW TRENDS IN THE DEVELOPMENT OF ION EXCHANGE METHODS}

Considering that separation of a particular wastewater into its components is not chemically difficult, the partical importance of the methods is estimated from economical aspects. The same applies to the application of ion exchange 


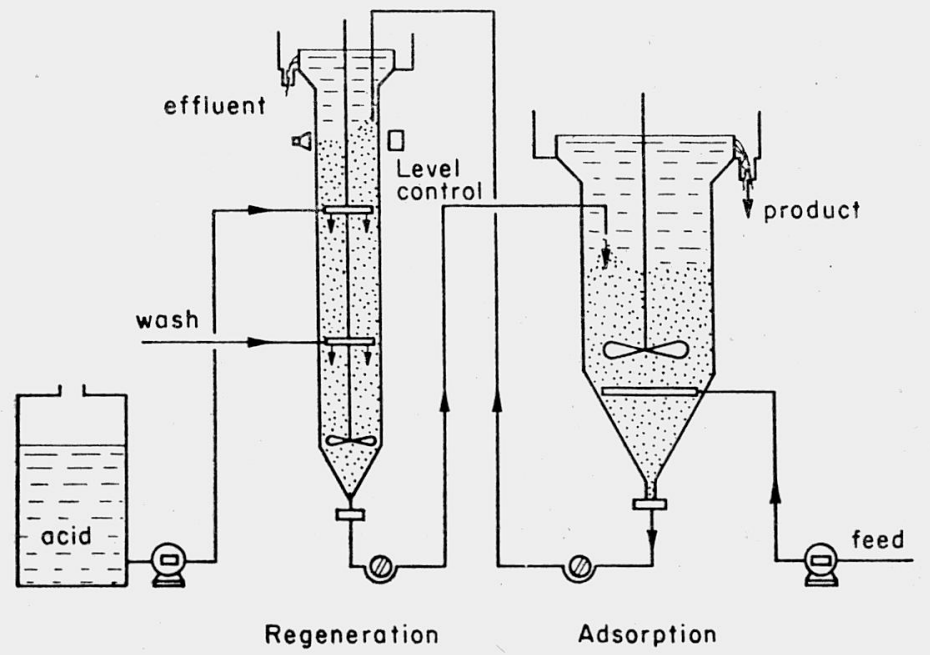

Fig. 2. Flow-sheet for a moving bed system with a fluidized bed adsorber unit Rys. 2. Schemat technologiczny układu złoża ruchomego z zespołem złoże fluidalne-adsorber

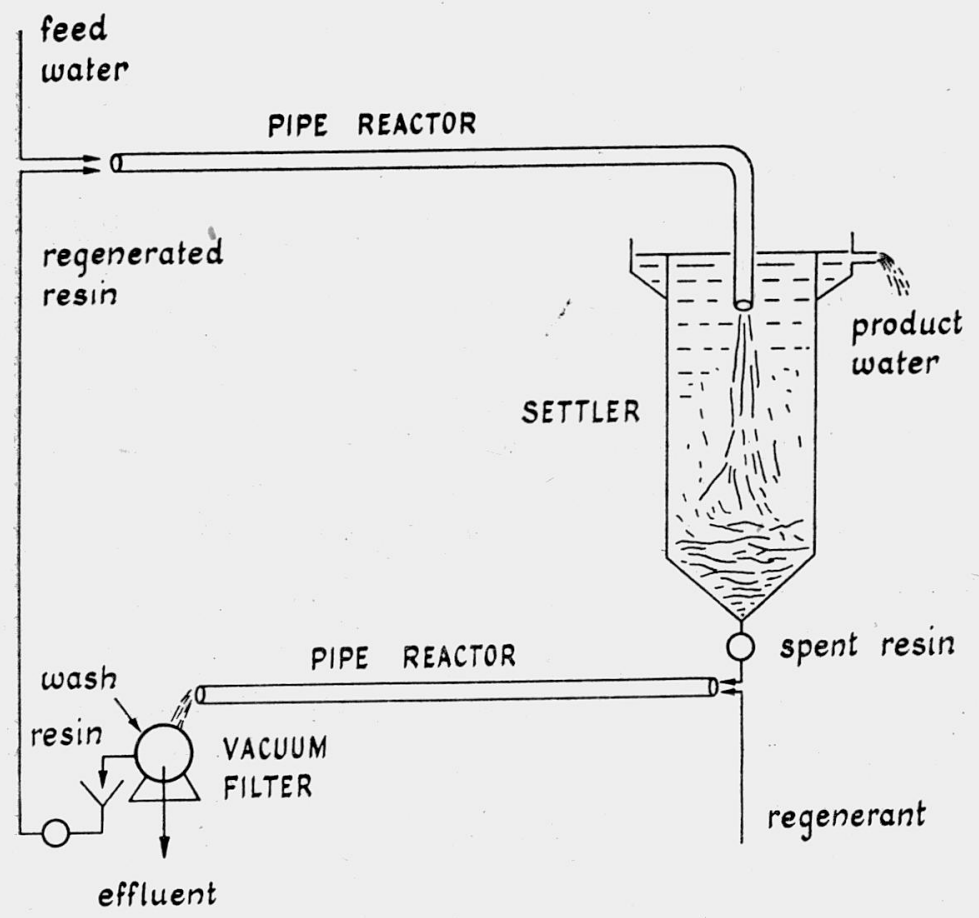

Fig. 3. Generalized flow-sheet based on entrained pipe reactors Rys. 3. Uogólniony schemat blokowy oparty na reaktorach rurowych 
to the recycling of wastewater constituents. In this case, the efficient separation of wastewater into concentrated salts and water is often too expensive, especially for large amounts of wastewater. Therefore the improvements in the unit operations and ion exchange materials are equally important as the development of new technological flowsheets for the process.

Having this in mind, CSIRO researchers invented magnetic resins, which have a considerable number of advantages [5], [6]. Since small (ca. $200 \mu \mathrm{m}$ across) resin particles are employed, the adsorption rate significantly increases. Due to the increased processing intensity, the same result can be achieved with smaller amounts of resin and in a smaller plant. The magnetized resins, being easily separated from treated waters and readily transferred, are ideal for continuous contactors, several forms of which have been studied [6], [7]. They all involve really continuous transfer of resin and not an intermittent one as is the case in most existing continuous processes.

Magnetized resins require a very simple equipment ranging from countercurrent-fluidized beds [9] to co-current entrimed pipe reactors [8], as depieted. in figs. 2 and 3. Both these systems have been tested on the pilot scale.

The fluidized bed system compared with a conventional continuous contactor of the Asahi type requires only about $25 \%$ of the resin [9]. Complexities in large-scale operation can be avoided by using an entrained pipe reactor, the capital cost of which for a $5 \mathrm{ML} /$ day system being about half that of the fluidized bed [8]. These plants are appropriate for reactions such as dealkalization, which requires only one or two stages.

A multistage version of the fluidized bed column constructed more recently contains perforated dividing plates and a stirrer in each compartment. It was specifically designed for the use of hot water as the regenerant [7] and tested in a desalination pilot plant. A1 ML/day demonstration unit is already constructed.

One of the main benefits of magnetic resin system, in contrast to the normal packed bed techniques, is that they can be used to treat raw water containing: suspended matter without the system clogging up. This is especially important when the cost of wastewater treatment can be reduced by avoiding preclarification. For example, a weakly acidic magnetic resin has been used to dealkalize unfiltered primary sewage effluent treated with lime [8].

For economical wastewater vieatment the concentration of contaminants in the regeneration effluent should be the highest possible, since they ensure their economical recycling. Theoretically, highly concentrated effluent should be produced when using the columns operated in a continuous counter-current manner. If, however, a highly concentrated solution is used for regeneration of the resin, the ratio of the regeneration solution to the resin should be low, as the concentration of ions to be removed from the resin never exceeds $2 \mathrm{eq} / \mathrm{dm}^{3}$ of the resin. In a semicontinuous counter-current unit, the movement of the 
resin in the column is achieved by a hydraulic pulse (for example in the Higgins unit). The liquid moves beyond the resin, which means that some of the regeneration solution will slip into the rinse section. At the same time, the exhausted resin brings some raw water into the regeneration section (see fig. 4).

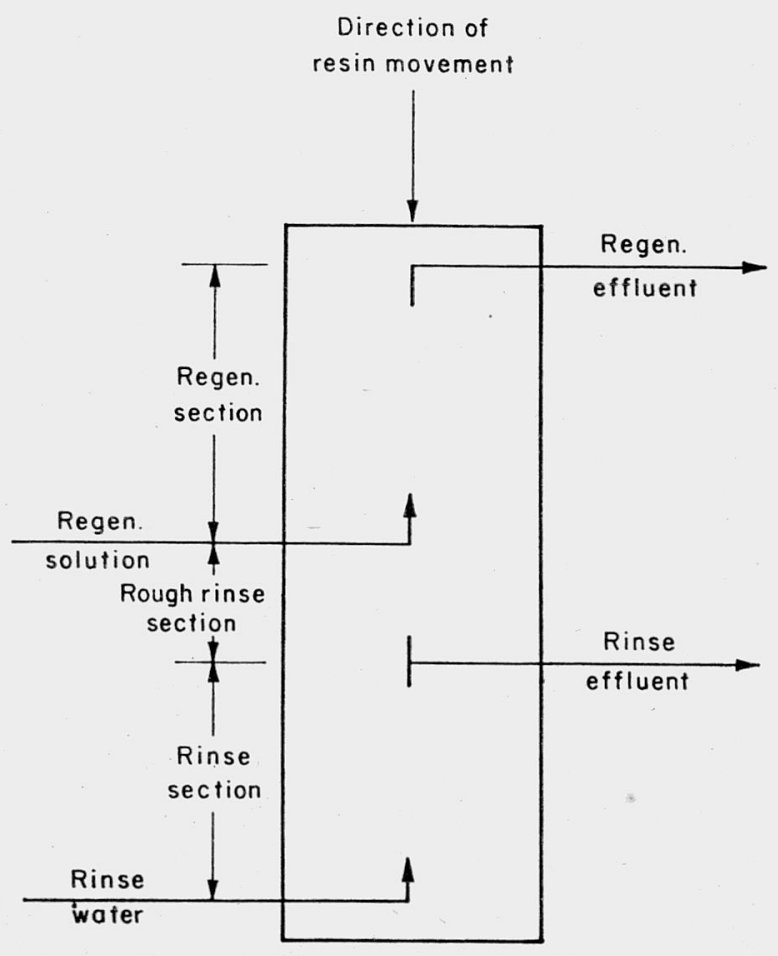

Fig. 4. Section of a moving bed system

Rys. 4. Odcinek układu ruchomego złoża

The regeneration effluent from the rinse section is pushed back into the regeneration section by the rinse water during the "working mode". However, at the very beginning of each working mode, the first part of the regeneration effluent is raw water brought in during the resin movement. This leads to dilution of the regeneration effluent. Theoretically, it should be possible to partition-off the regeneration effluent by separating the first part of the liquid from the other more concentrated position. Due to the short pulse times involved, this separation may not be easy to achieve. A truly continuous countercurrent column should reduce this dilution effect, a proper flow balance being ensured by a steady state system. In fluidized bed systems backmixing must be carefully controlled.

According to [6] a series of functional types of magnetic resins can be 
prepared. The simplest forms are those in which the magnetic component, usually about $20-50 \%$ by weight, is present within a bead or granule of an otherwise conventional resin structure. The particle size of about $100 \mu \mathrm{m}$ across is smaller versus $300-1200 \mu \mathrm{m}$ for conventional resins. Polystyrene derived resins having strongly acidic and strongly or weakly basic characteristics can be readily synthetized.

Resins, even more rapidly reacting, can be obtained by grafting the active ion exchange polymer onto an inert magnetic polymer core, such as that obtained by dispersing the magnetic material throughout a crosslinked polyvinyl alcohol. In this way weakly acidic resins based on polyacrylic acid have been successfully prepared [6]. The exchange sites in such "whisker" resins are more accessible, so that the rate advantage is five times that of a conventional weakly acidic resin of the same size. The weakly acidic groups can be converted to other funcionalities by various synthetic steps, but the linkage of the active group to the polymer chain usually involves a hydrolytically unstable ester or amide group [10]. It is our belief that the future development of these resins will further reduce the cost of ion exchange as applied to the recycling of wastewater constituents.

\subsection{REVIEW OF FLOWSHEETS FOR WASTEWATER TREATMENT WITH MAGNETIC RESINS}

The most important features of magnetic resins - fast reaction and easy transfer during operation in a continuous system - permit simplification of plant design and size, making magnetic systems more competitive with the existing technology.

One of their biggest potential areas of application is removal of heavy metals from industrial wastewater and sewage. An application of magnetic resins to the recycling of wastewater components (nickel salts) from the rinse water of metal finishing industries is illustrated in fig. 5. Recycling of other types of rinse waters by using magnetic resins would be very similar. Another possible example is the removal of metals from mixed plating effluents (see fig. 6).

Magnetic resins can also be applied to sewage treatment, especially when the treatment involves the liquids which initially contain suspended matter [8] or those containing precipitates formed during the ion exchange operation, as for example in the Liberti process [37]-[39]. (fig. 7). Even the adsorbent clinoptilolite, which is used for $\mathrm{NH}_{4}^{+}$removal, can be converted into a magnetic mode by the synthesis of a composite bead containing the finely divided adsorbent and iron oxide within an inert polymeric binder such as crosslinked polyvinyl alcohol. This is a variation on the magnetic activated carbon particles devised by the CSIRO magnetics program [19]. Although the capacity of the magnetic particle is reduced because $40 \%$ of the bead volume consis- 


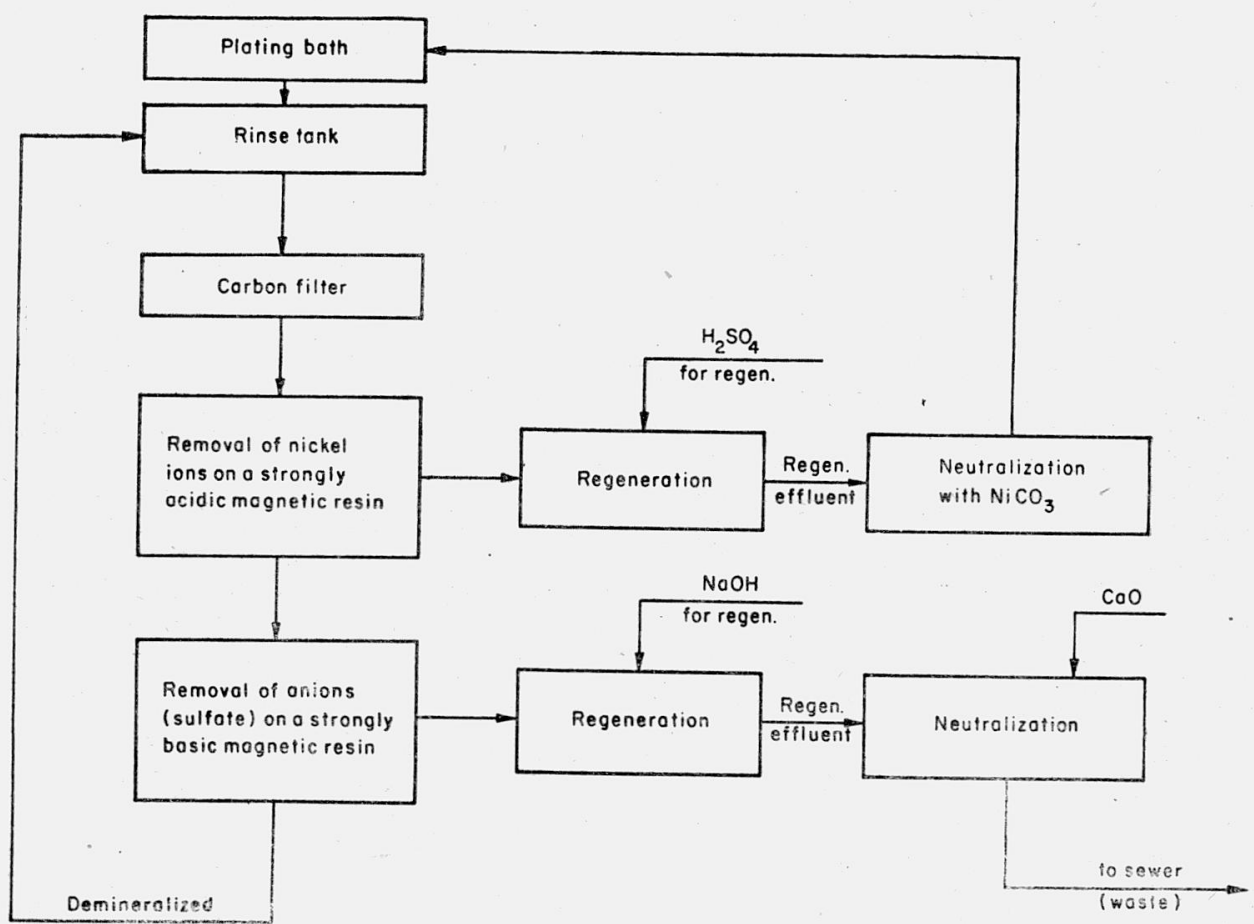

Fig. 5. Flow-sheet for the recovery of nickel from rinse water Rys. 5. Schemat blokowy odzysku niklu z wody płuczącej

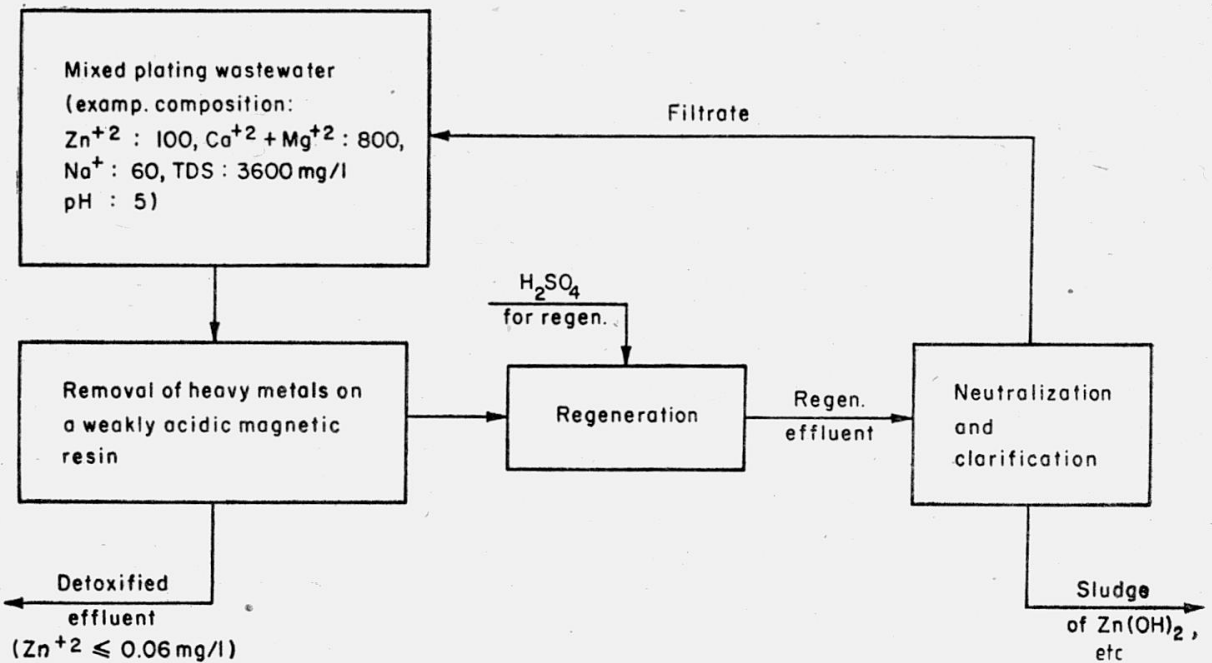

Fig. 6. Flow-sheet for the purification of mixed plating wastewater Rys. 6. Schemat blokowy oczyszczania ścieków mieszanych z galwanizerni 


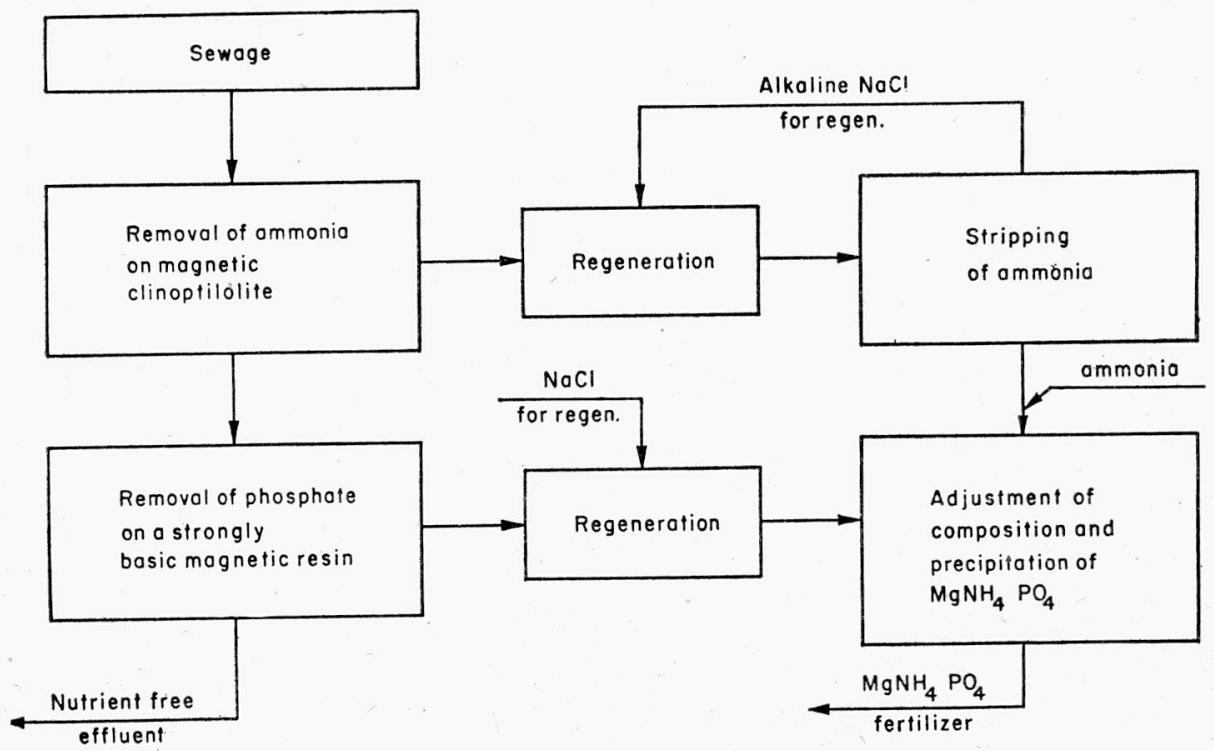

Fig. 7. Flow-sheet for the recovery of nutrients from sewage

Rys. 7. Schemat blokowy odzysku związków biogennych ze ścieków

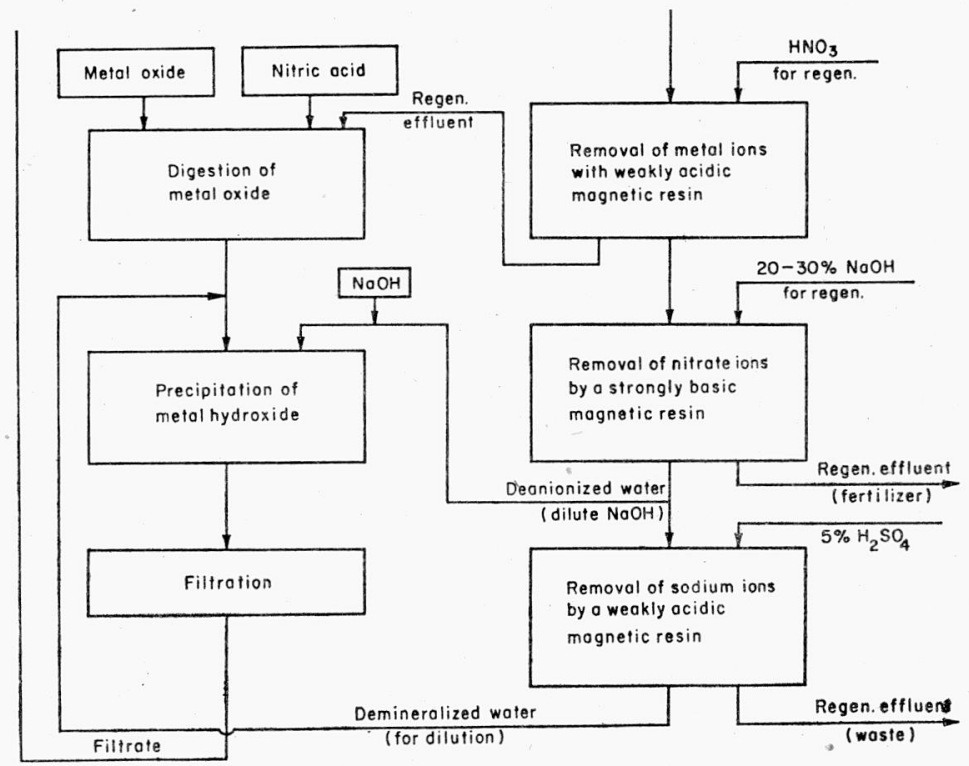

Fig. 8. Flow-sheet for a closed-loop system of processing of heavy metal oxide catalysts Rys. 8. Schemat blokowy systemu zamkniętego obróbki tlenków katalizatorów metali ciężkich 


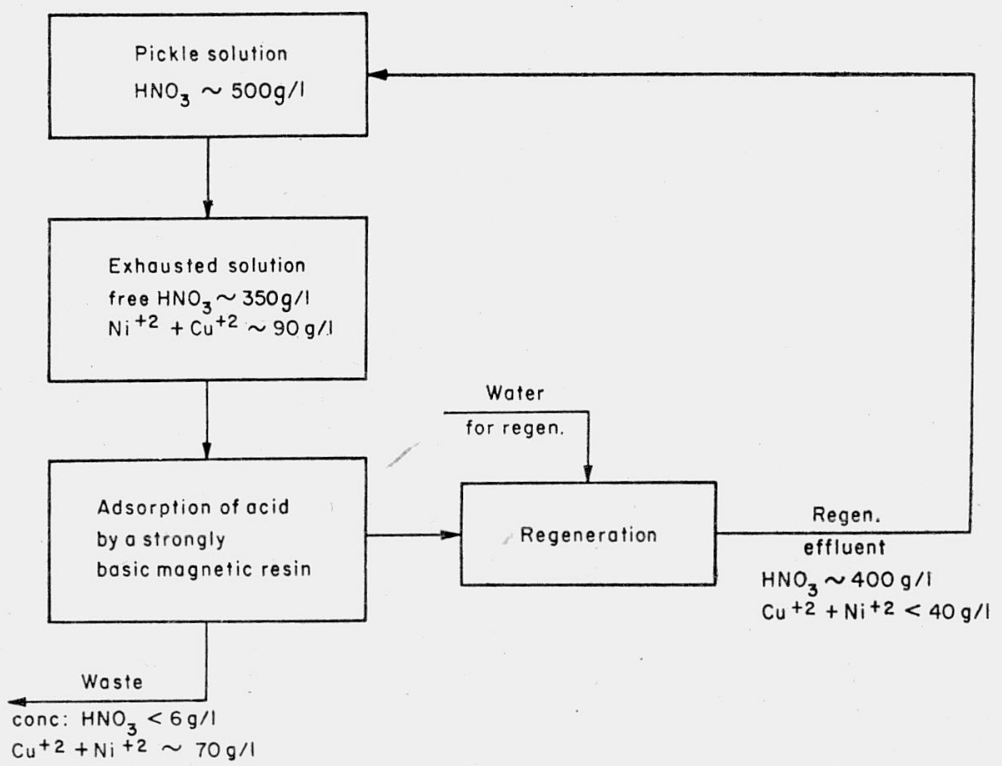

Fig. 9. Flow-sheet for the separation of acids and salts by ion exchange Rys. 9. Schemat blokowy rozdziału kwasów i soli przez wymianę jonową

ts of inert material, the adsorption rates are enhanced by one order of magnitude. The mechanical strength of the particles is also considerably improved.

One of the most economical and practical approaches to wastewater treatment is its integration with the basic manufacturing process, as for instance the integrated system which is employed in the manufacture of metal oxides and can be operated with magnetic resins (see fig. 8).

Another area, where the use of the magnetic resin would be beneficial, is the separation of an acid from its salts (fig. 9). When conventional resins are employed, the process is limited by slow kinetics [55]. The use of a magnetic micro-resin with its far better kinetic properties should increase the possibility of the acid retardation process in the wastewater area. Other processes, which would benefit from the use of magnetic resins and whose preliminary laboratory studies have been carried out, are colour removal from paper-mill bleach plant effluent [11] and the recovery of organic compounds in the food industry [24].

These few examples illustrate the ways in which the unique properties of magnetic resins might be used for treatment of various wastewaters. One magnetic resin of the magnetic whisker type, besides the fact that it maintains suspended matter in the contacting equipment, has also another advantages. Since the active polymer chains, grafted to the magnetic core, are essentially uncrosslinked, the contamination of resin fouling does not seem to occur. As 
already mentioned, a weakly acidic whisker resin has been successfully used in pilot plant studies for the removal of calcium bicarbonate from lime-treated primary sewage effluent [8]. Further applications are suggested in figs. 6 and 8 [6]. So far, not much has been done on the application of magnetic resins to wastewater treatment.

The concept of magnetic resin application to the removal of insoluble contaminants has been successfully developed in large scale operations [2]. Although the removal of suspended matter with magnetic whisker resins based on grafted cationic polymers is possible, the process is too expensive to compete with conventional clarification in which alum, iron salts or lime are used. It has been found, however, that iron oxide particles alone can be employed for adsorption of dissolved materials, and heterocoagulation of colloidal and suspended matter. Magnetite of diameter $1-10 \mu \mathrm{m}$ has positive surface charge at slightly acidic $\mathrm{pH}$ values ( 5 to 6 ) and it effectively removes colour anions and clays, silica and microbes which at that $\mathrm{pH}$ are all negatively charged. The addition of a soiuble cationic polyelectrolyte increases the capacity of the magnetite. Rapid separation of the treated water and magnetite is achieved after magnetization, and the oxide can be regenerated by raising the $\mathrm{pH}$ level to 11.5 , whereupon the surface charge is reversed so that the like-charged impurities are released. The process has been proved for the turbidity and colour removal from underground and surface waters [2], more recently, attention has been focussed on wastewaters, including effluents from a steel cold rolling mill, textile dyehouse, secondary sludge treatment plant, and papermaking [3].

We believe that the unusual characteristics of the new reagent particles will guarantee their future usage.

\section{REFERENCES}

[1] Anderson R. E., Some examples of the concentration of trace heavy metals with ion exchange resins, Report No. EPA - 902/9-74-001, US EPA, Cincinnati, 1976.

[2] Anderson N. J., Blesing N. V., Bolto B.A., Dixon D. R., Kolarik L. O., Nadebaum P.R., Priestley A. J., Raper W. G. C., Weiss D. E., Water clarification with the use of regenerable magnetic particles, Effl. Water Treat. J., 1981, 21, 359-366.

[3] Anderson N. J., Bolto B. A., Dixon D. R., Kolarik L. O., Priestley A. J., RAPER W. G. C., Water and wastewater treatment with reusable magnetic particles, Water Science and Tech., accepted for publication.

[4] ARION N. M., Treating and recovering, wastewater from fertilizer manufacture, USA Pat. 4002455 (1977).

[5] Blesing N. V., Bolto B. A., Ford D. L., MeNeirl R., Macpherson A. S., MelbourNe J. D., Mort F., Siudak R., Swinton E. A., Weiss D. E., Willis D., Some ion exchange processes for partial demineralization, Ion Exchange Processes in Pollution Control, Society of Chemical Industry, pp. 371-381, London 1970.

[6] Bolto B.A., Magnetic microresins, [in:] Ion Exchange Processes in Pollution Control, 
Vol. 2, ed. by C. Calmon and H. Gold, CRC Press, Boca Raton, Fla., 1979, pp. 213-225.

[7] Bolto B. A., Swinton E. A., Nadebaum P. R., Nurtagh R. W., Desalination by continuous ion exchange based on thermally regenerable magnetic microresins, Water Science and Technology, accepted for publication.

[8] Bolto B. A., Dixon D. R., Priestley A. J., Swinton E. A., Ion exchange in a moving bed of magnetized resin, Prog. Water Tech., 1977, 9, 833-844.

[9] Bolto B. A., Dixon D. R., Eldridge R. J., Kolarik L. O., Priestley A. J., RaPer W. G. C., Rowney J. E., Swinton E. A., Weiss D. W., Continuous ion exchange using magnetic microresins, The Theory and Practice of Ion Exchange, Society of Chemical Industry, paper 27, London 1976.

[10] Bolto B. A., Dixon D. R., Eldridge R. J., Graft polymerization on magnetic polymer substrates, J. Appl. Polym. Sci., 1978, 22, 1977-1982.

[11] Bolto B. A., Priestley A. J., Siudak R. V., A continuous process for decolorizing hardwood caustic bleach plant effluent using a magnetic basic ion exchange resin, Appita 1979 , $32,373-377$.

[12] Bolto B. A., Paweowski L., Reclamation of wastewater constituents by ion exchange, Effl. Water Treat. J., accepted for publication.

[13] Calmon C., Ion Exchange for Pollution Control, ed. by C. Calmon and H. Gold, CRS: Press, 1979; a) Mercury removal by ion exchange, pp. 201-206, b) Precious metal recovery, pp. 213-215, c) Specific ion exchangers, pp. 151-154.

[14] Calmon C., Specific and chelate exchangers: new functional polymers for water and wastewater treatment, Journal AWWA, 1981, 652-656.

[15] Chamberlain D. G., Selective removal of zinc from cooling tower blowdown by ion exchange, Proc. Int. Water Conference, Pittsburgh 1970.

[16] Cooley Austin C., Ion exchange silver recovery for process EP- 2 with nonregenerated bleach-fix, J. Appl. Photogr. Eng., 1981, 7, 106-110.

[17] Costa R. L., Regeneration of chromic acid solutions by ion exchange, Ind. Eng. Chem., 1950, 42, 308-311.

[18] DE Yong G. J., Rekens C. J. N., AKZO process: for removal of mercury, J. Chromatography, 1974, 443-450.

[19] Dixon D. R., Lydiate J., Selective magnetic adsorbents, J. Macromol, Sci-Chem., 1980, A14, 153-159.

[20] Gemert J. T., Using and recovering silver, Industrial and Commercial Photography, 1980 April/May, 42-43.

[21] Gnот W., Kociubas Z., Recovery of mercury from wastewaters in the electrolytic production of chlorine, Zesz. Nauk. Politech. Śląsk. Chem., 1979, 57-69.

[22] Gold H., Metal finishing wastes, Ion Exchange for Pollution Control, ed. by C. Calvin and H. Gold., CRS Press, 1969, p 173.

[23] Grant P.J., Schepers J. R., Power plant water purification, chemical recovery and waste-treatment: a novel technique with multiple in plant application, Proc. Amer. Power Conf., 1978, 975-985.

[24] Grant R. A., Protein recovery as an effluent treatment process, Effl. Water Treat. J., $1975,15,616-620$.

[25] Grintsead R. R., Nasutavicus W. A., Wheaton R. M., New selective ion exchange resins for copper and nickel recovery, Extractive Metallurgy of Copper, American Institute of Mining, Metallurgical and Petroleum Engineers, 1976.

[26] Grinstead R. R., Copper-selective ion exchange resin with improved iron rejection, Journal of Metals, $1979,31,13-16$. 
[27] Hatch J., Dillon J. A., Acid retardation, Ind. Eng. Chem. Process Design and Development, 1963, 2, 253-263.

[28] Heijwegen C. P., Van Zijll Langhout P. A., Treatment of waste liquid from the electrolytic tin-coating lines at Hoogovens Jmuiden B. V., Belg.-Ned. Tijdschr. Oppervlaktetech Mater., 1980, 24, 162-168.

[29] Henmi Eirch, Recovery of gold in washings of acid gold-plating bath, Jap. Patent 7768023 (1977).

[30] Higgins I. R., Chopra R. C., Roland L. D., Continuous ion exchange achieves unique solution in pollution control, Inst. Chem. Eng. Symp. Ser., 1978, 54, 105-110.

[31] Inoue Takashi, Matsuoka Makoto, Nimura Takeo, Uejima Hiromoto, Vanadium and nickel recovery from desulfurization solution, Jap. Patent 7890653 (1978).

[32] Ito YU'tAKA, Apparatus and method for recovering boric acid from radioactive waste solutions, Jap. Patent 8000430 (1978).

[33] Joffe A. Z., Chamaev V. N., Markowa L.M., Kulebyakina L.A., Reduction in environmental pollution by wastewater from cuprammonium fibre production, Khim. Volokna, $1979,4,50-51$.

[34] JoNes K. C., PYJOER R. A., Copper recovery from acidic bleaching liquors by continuous ion exchange and electrowinning, Journal of Metals, 1979, 31, 19-25.

[35] Kawamoto Michio, Murakami Hiroyoshi., Recovery of selenium oxyacids in wastewater, Jap. Patent 78108898 (1978).

[36] Kunin R., Ion exchange for the metal products finisher, Prod. Finish (Cincinnati), AprilJune 1969.

[37] Liberti L., Limoni N., Passino R., Petruzzeldi D., Ammonium phosphate recovery from urban sewage by selective ion exchange, Physicochemical methods for water and wastewater treatment. ed. by L. Pawłowski, Pergamon Press, 1980, pp. 73-85.

[38] Liberti L. Passino R., An ion exchange process to recover nutrients from sewage, Resource Recovery and Conservation, 1981, 6, 263-273.

[39] Liberti L., Limoni N., Petruzzelli D., Nutrient removal from sewages by selective ion exchange, Quard.-wst. Ric. Acque, 1979, 38, 13/1-13/25.

[40] Makita Zenji, Hayashi Masami, Utsugi Minoru, Recovery of high purity zine, Jap. Patent 7761125 (1977).

[41] Mina R., Silver recovery from photographic effluents by ion exchange methods, J. of Appl. Photogr. Eng., 1980, 6, 120-125.

[42] Nagata Masanori, Uchino Yoshitoshi, Kubota Noboru, Honda Yukio, Takada. Томоко, Wastewater treatment in electronic parts plating plant and metal recovery - gold recovery from plating rinse wastewater by ion exchange, Kenkyu Hokoku - Kymamotoken Kogyo Shikenjo, 1979, 8-13 (Chem. abstracts 94: 6282).

[43] Nagata Masanori, Uchino Yoshitoshi, Kuboto Noboru, Wastewater treatment and recovery of useful materials from electronic part plating factories. I. Recovery of silver from wastewater by ion exchange, Kumamoto-krn Kogyo Shikenjo, Kenkyu Hokoku, 1976, 51, 12-19. (Chem. abstracts 99: 435549).

[44] Nagata Masonori, Honda Yukio, Kuboto Noboru, Uchino Yoshitoshi, Takata Томоко, Investigations on the treatment of effluents from electronic component parts plating plants and the recovery of valuables. V. Experiments on the recovery of silver from silver plating wastewaters, Kumamoto-ken Kogyo Shikenjo, Kenkyu Hokoku, 1977, 52, 24-35 (Chem. abstracts 90: 172075).

[45] Paweowski L., Cichocki A., KuHnke T., Note on a continuous counter-current ion exchange with two step regeneration for zinc recovery from synthetic fibre plant wastewater, Water Res., 1976, 10, 781-782. 
[46] Paweowski L., Klepack B., Zalewski R., A new method of regeneration of anion exchanger used for recovering chromates from wastewater, Water Res., 1981, 15, 1153-1156.

[47] PawŁowski L., Pilot plant study of ammonia and water recycling in the nitrogen industry, Resource Recovery and Conservation, 1979, 4, 43-57.

[48] Popovicr I. V., Technical solutions and technical advances made in Romania to control environmental pollution effects arising from fertilizer plants, UNIDO, TD/WG 175/18, Expert Group Meeting, Helsinki 1974.

[49] Roland L. D., The recovery of ammonium nitrate from fertilizer factory wastes, Physicochemical Methods for Water and Wastewater Treatment, ed. by L. Pawłowski, Pergamon Press, 1980, pp. 299-311.

[50] Shuldt A. A., Huber R., Chromate and water recovery from tin plating operation using ion exchange technologies, Proc. Int. Water Conf. Eng. Soc. West Pa., 1978, 38, 185-199.

[51] Stromquiest D. M., Reents A. C., Removal of cations from chromic acid solutions, Proc. 6th Ind. Waste Conf., Series 76, p. 289, Purdue University, Lafayette, Ind., 1952.

[52] Ueshima Hiromoto, Yamashita Shintaro, Muranishi Seichiro, Murakami Hiroyoshi, Окамото MitsutaMi, Recovery and recycling of selenium values from a spent aluminium electrolytic colouring bath, Jap. Patent 79155945 (1979).

[53] Umarakhunov M. K., Kaplan A. L., Shamsiev S. M., Rezqev N. U., Optimization of the separation of molybdenum from nitre and carbonate ions on the anion exchanger A V-17 in chloride form, Deposited Doc., 1974, VINITI 2808-74.

[54] Usenima Hiromoto, Shinmura Takeo, Murakami Hiroyoshi, Okamoto Mitsutami, Recovery of selenium from wastewater from the electrolytic colouring process of aluminium and its reuse, Jap. Patent 7980194 (1977).

[55] Vis J. H., Mercury recovery from waste streams by means of the Imac TMR ion exchange process, Chem. Age. India, 1980, 31, 481-487.

[56] Vlasova V. I., Petryaev E. P., Afanaseva T. S., Treatment of arsenic-containing wastewater by ion-exchange sorption, Jzv. Vyssh. Uchelon. Zaved. Khim. Khim. Teknol., 1971, 24, 212-215.

[57] WaItz W. H., Ion exchange in heavy metals removal and recovery, Amber Highlights, No. 162, Philadelphia 1979.

[58] YaBe EICHI, Treatment of plating waste solutions, Jap. Patent 7975159 (1977).

[59] Yones K. C., Grinstead R. R., Properties and hydrometallurgical applications of two new chelating ion exchange resins, Chem. and Ind., 1977, 637-641.

[60] Zagulski L., Paweowski L., Crchokr A., Methods for recovery of water and vanadium compounds from wastewater, Physicochemical Methods for Water and Wastewater Treatment, ed. by L. Pawłowski, Pergamon Press, 1980, pp. 229-236.

\section{ZASTOSOWANIE WYMIANY JONOWEJ \\ W RECYRKULACJI SKŁADNIKÓW ŚCIEKÓW}

Zawracanie do obiegu obecnych w ściekach substancji odpadowych wymaga stosowania wydajnych i tanich metod ich separacji i zatężania. Ponadto ścieki muszą byé oczyszczone do takiego stopnia, który umożliwi ponowne wykorzystanie wody. Jedną z bardzo wydajnych metod separacji jonów z roztworów wodnych jest wymiana jonowa, której użyteczność w technologiach oczyszczania ścieków jest często niedoceniana. Omówiono zastosowanie wymiany jonowej do odzysku metali, składników pokarmowych i rzadkich związków chemicznych (a także wody) ze ścieków przemysłowych i komunalnych. Szczególny nacisk 
położono na przedstawienie sposobów polepszenia ekonomiki odzysku tych substancji. Jedną z metod uproszczenia procesu i zmniejszenia jego kosztów jest zastosowanie żywic magnetycznych. Ich doskonałe właściwości kinetyczne umożliwiają maksymalne zmniejszenie gabarytów instalacji. Dokonano przeglądu obecnych i potencjalnych zastosowań tych żywic.

\section{DIE ANWENDUNG DES IONENAUSTAUSCHES \\ IM RÜCKFÜHRUNGSVERFAHREN VON ABWASSERINHALTSSTOFFEN}

Die Rückführung von abfallartigen Abwasserinhaltsstoffen benötigt die Anwendungvon ergiebigen und billigen Trenn- und Eindickungsmethoden. Die Abwässer müssen ausserdem soweit aufbereitet sein, daß eine Wasserrückführung möglich erscheint. Eine der ausgiebigen Ionentrennmethoden ist der Ionenaustausch, dessen Nützlichkeit in der Abwasserreinigung sehr oft unterschätzt wird. Im Beitrag wird die Anwendung des Ionenaustausches zur Metallgewinnung, Gewinnung von Nährstoffen und von seltenen, chemischen Substanzen (incl. des Wassers) aus kommunalen und industriellen Abwässern besprochen. Spezieller Augenmerk wurde den wirtschaftlichen Aspekten der Rückgewinnung gewidmet. Das Verfahren kann durch die Verwendung von magnetischen Harzen weitgehend vereinfacht und verbilligt werden. Aufgrund der hervorragenden, kinetischen Eigenschaften dieser Harze, können die entsprechenden Anlagen wesentlich kleiner gestaltet werden. Eine Übersicht der gegenwärtigen und der potentiellen Anwendung dieser Harze wird gegeben.

\section{ПРИМЕНЕНИЕ ИОННОГО ОБМЕНА В РЕЦИРКУЛЯЦИИ КОМПОНЕНТОВ СТОЧНЫХ ВОД}

Возврат в обращение присутствующих в сточных водах отходных веществ требует применения производительных и дешёвых методов их сепарации и концентрирования. Кроме того, сточные воды должны быть очищены до такой степени, которая даст возможность повторного использования воды. Одним из высокопроизводительных методов сепарации ионов из водных растворов является ионный обмен, полезность которого в технологиях очистки сточных вод часто не доценивается. Обсуждено применение ионного обмена для извлечения металлов, кормовых компонентов и редких химических соединений (а также воды) из промышленных и коммунальных сточных вод. Особенный упор сделан на представление составов улучшения экономики извлечения этих веществ. Одним из методов упрощения процесса и уменьшения его стоимости является применение магнитных смол. Их превосходные кинетические свойства позволяют максимально уменьшить габаритья установки. Произведён обзор настоящих и шотенциальных применений этих смол. 